\title{
Notes on Constitutional Endurance
}

\author{
Dag Anckar \\ Department of Political Science, Åbo Akademi University, Turku, Finland \\ Email: dag.anckar@abo.fi
}

Received 17 December 2013; revised 15 January 2014; accepted 11 February 2014

Copyright (C) 2014 by author and Scientific Research Publishing Inc.

This work is licensed under the Creative Commons Attribution International License (CC BY).

http://creativecommons.org/licenses/by/4.0/

c) (i) Open Access

\begin{abstract}
Among the countries of the world there are great differences in terms of constitutional endurance, i.e. the life span of national constitutions. Exploring these differences the literature in this field has observed associations between democracy and constitutional survival, and this article contributes in the form of a case study to the still somewhat fragmentary evidence for a correlation. Investigating a set of countries composed of former British colonies, the study shows that clearly more than semi-democratic and non-democratic colonies, the democratic colonies have been during independence endurance guardians. However, the good endurance record may follow from the fact that more than other states democracies change their constitutions by means of individual amendments to constitutional texts rather than by constitutional turnover. There is therefore a need for future endurance studies to probe deeper into the amendment institution. Of several other endurance aspects that are brought to the fore in the study, one is about regional differences and particularly about the case of Africa, which stands out as a place for an ongoing vast constitutional muddle and reshuffle. Indeed, of more than 80 constitutions introduced in the world in the 1990s, no less than 38 were adopted by African states. Since several of these transitions have implied a rejection of one-party rule and one-party elections and a growing acceptance of competitive elections, the African endurance gap may in the long run prove beneficial to political development.
\end{abstract}

\section{Keywords}

Constitution; Constitutional Endurance; Constitutional Rigidity; Democracy; Endurance Research

\section{Introduction}

Almost all countries in the world have written constitutions-Britain, Israel and New Zealand are notable exceptions. The constitutional texts differ much in terms of structure, content and background factors, and offer a rich field of study for disciplines like comparative constitutional law and comparative politics. This essay is about variations among countries in terms of constitutional endurance, i.e. the time span between the adoption 
and the abolishment of particular national constitutions. This variation is truly remarkable: whereas some valid constitutions are even very old, like those of the United States (1789), Norway (1814) and Luxembourg (1868), others, like those of Finland (2000), Maldives (2008) and Kenya (2010) are of very recent origin.

Somewhere in the terrain between very old and very recent is an average figure that evens out the difference between old and new. Concerning this average lifespan, the literature reports a quite amazing observation on the correspondence between theory and reality. Long ago, Thomas Jefferson, arguing that the dead had no right to govern the living, calculated the precise period after which a current majority should preferably be replaced by a new one, and he found that constitutional replacement should take place every 19 years so that each generation could determine its own fundamental rules (Ginsberg, 2011: p. 113). Some years ago, the now landmark study in this field by Elkins, Ginsberg and Melton (2009), reported that the lifespan for constitutions for all countries in the world is, believe it or not, 19 years! Jeffersonian clear-sightedness or mere chance-maybe both. Anyhow, the valid lesson from an abundance of studies in constitutional engineering is that different countries, and obviously for a variety of reasons, behave differently in regards to the Jefferson standard. Some have chosen to disregard the standard and indeed allow former majorities to govern current majorities, others have changed their constitutional frameworks at more or less the same pace by which generations succeed each other, still others exchange frameworks at even shorter intervals.

The notes that follow discuss various aspects of constitutional endurance and dwell upon endurance appearances as well as causes of endurance and patterns of endurance studies. An emphasis is on the relationship between democracy and endurance which is highlighted here by means also of a new set of empirical materials. The two following sections of this essay deal at some length with this particular relationship, whereas the two concluding sections, on regions and on rigidity, deal with somewhat separate issues.

\section{Democracy and Endurance}

Summarizing the literature on the costs and benefits of endurance, Ginsberg (2011) concludes that "countries with enduring constitutions are richer and more democratic" (p. 114). He hastens to note that the relationship between endurance and other goods is likely to be complex and multi-channeled (p. 114); however, he finds, on the whole, that the suggestive evidence is strong for a link between democracy and endurance (p. 115). The following case study adds to this suggestive evidence.

The study is about fifty-four territories that have since World War II been freed from British rule. All these former colonies, with the exception of South Yemen, exist today as independent states. They can be found in almost all corners of the globe, they represent a great variety of political regimes and governance models, and they display a variegated set of institutional settings. Concerning democratic status, on the basis of an available listing (Anckar, 2011), the colonies may be ordered in three categories, one which denotes full-fledged democracies, one which comprises non-democracies, and one which denotes semi-democracies, i.e. cases which do not really qualify for inclusion in the two first categories. There are in all 17 cases in the first category; however, due to the lack of a written constitution, Israel and New Zealand are excluded here from consideration. There are 22 cases in the second category; for a lack of a central government, however, Somalia is excluded from analysis. Finally, there are 14 cases in the third category. Given the prescribed frame of reference of this case study, the ensuing expectation is, of course, that the level of endurance is high in the first category, low in the second category, and between high and low in the third category.

Before turning to findings, the methods used for determining democracy status and for measuring endurance must be explained. Concerning democracy, democratic status is defined in terms of the frequently used Freedom House classifications since 1972 of the countries of the world in categories of "Free", "Partly Free" and "Not Free" countries; as customary in democracy studies, countries that are classified as "Free" are regarded here to be democracies (Anckar, 2011: pp. 54-57). On the basis of these classifications, each country is assigned a percentage value, which is a measure of how frequently the country in question has been since independence up to the year 2010 rated as democratic. To give an example, a colony which became independent in, say, 1975, and has been ranked thereafter by Freedom House each year in the time span 1976-2010, has thirty-five classifications. If all the rankings have been in the democracy category, the democracy rating of this country is 100 . If the country has not once been ranked in the democracy category, the democracy rating is 0 . And if the country is ranked in the democracy category, say, fourteen of thirty-five times, the resulting percentage calculation gives the country a democracy rating of 40 . 
In regards to endurance, the measure that is used is the number of constitutions that have been adopted in each country during the time span from independence up to the year 2010. The primary data source is "Constitutions of the Countries of the World", a series of updated constitutional texts by Oceana Publications (Flanz, various years), which is an excellent guide to the constitutions and constitution-like texts from all parts of the globe. Not only contain the editions complete constitutional texts; in several cases the editorial efforts also provide expert commentaries as well as historical notes and reviews and annotated bibliographies. The relevant data on democracy and endurance are brought together in Table 1, which reports for each former colony its democracy rating and number of constitutions. For instance, the notion Bahamas (100-1) indicates that Bahamas has always during independence been classified by Freedom House as a democracy, and has adopted one constitution only, namely the independence constitution from the year 1973. In contrast, the mark Maldives (5-3) indicates that the Maldives has only at very few occasions been classified as a democracy but has since independence in 1965 from British rule adopted three national constitutions (1968, 1998, 2008).

The empirical patterns that emerge from Table 1 are the following:

Of the 15 members of the democracy group, no less than 13 have adopted one constitution only, this meaning that they have excellent endurance rankings. The two exceptions, Trinidad and Tobago as well as Tuvalu, have both adopted two constitutions; the average endurance score in this group is therefore 1.13. Although modest, this figure may to some extent magnify unduly the tendency of this group of democracies to engage in constitutional turnover-the constitutional change evoked in Trinidad and Tobago and Tuvalu by means of new constitutions was in both cases rather marginal. In the case of Trinidad and Tobago the 1976 Constitution that replaced the 1962 independence constitution fore-mostly signified that the country became a republic; compared to the older constitution, the substantive changes were minimal. The Tuvalu Constitution of 1986 that replaced the 1978 independence constitution basically proclaims in a new preamble and a new chapter on constitutional principles the fundamental importance of Tuvaluan culture and customs as foundations of the state (Somoza, 2001: pp. 824-825). In sum, the belief that democracy promotes endurance gains much support from the above findings. The group consists of democracies, and their endurance performances are close to perfect.

In the group of 21 non-democracies, only four members have experienced short and non-frequent periods of democratic rule. Among them are Zambia, the first English-speaking African country to re-introduce multi-party politics, although for a few years only (Krennerich, 1999b: p. 939), and the Seychelles, where in the wake of independence in 1976 a brief period of consociational politics was interrupted by a coup and where a full return to democratic politics has not yet been implemented (Thibaut, 1999: pp. 775-778). One third of these non-democratic entities have adopted one constitution only, whereas the remaining two thirds have adopted two or more constitutions. For nine countries the record is three or more constitutions; the average endurance score is 2.24. Evidently, then, the endurance connection is much weaker in this democracy-impoverished group of states. Although some non-democracies have good endurance records, a majority, including Maldives, Myanmar, Sudan, Swaziland, Tanzania, Uganda, Zambia, and others manage poorly in terms of constitutional endurance.

In the in-between group with 14 members, the democracy scores are fairly dispersed. Some members, like Cyprus, Grenada, India, Solomon Islands and Vanuatu stand for democracy performances that while not stainless still come fairly close to a democracy rank. Others, like Lesotho, Malawi, Nigeria and Sri Lanka, have

\section{Table 1. Democracy ratings and number of constitutions from independence to 2010 in three sets of countries.}

Democracies. Average: 1.13

Bahamas (100-1), Barbados (100-1), Belize (100-1), Botswana (97-1), Dominica (100-1), Jamaica (100-1), Kiribati (100-1), Malta (86-1), Mauritius (100-1), Nauru (100-1), St Kitts-Nevis (100-1), St Lucia (100-1), St Vincent (100-1), Trinidad and Tobago (97-2), Tuvalu (100-2)

$\begin{array}{r}\text { Semi-democracies. Average: } 2.14 \\ \hline \begin{array}{r}\text { Antigua-Barbuda (53-1), Cyprus (81-1), Fiji (41-3), Gambia (38-3), Ghana (30-4), Grenada (77-1), Guyana (46-2), India (76-1), Lesotho } \\ \text { (19-2), Malawi (14-2), Nigeria (11-5), Solomon Islands (70-1), Sri Lanka (22-3), Vanuatu (76-1) }\end{array} \\ \text { Non-democracies. Average: } 2.24 \\ \hline \begin{array}{r}\text { Bahrain (0-2), Brunei (0-1), Jordan (0-2), Kenya (0-2), Kuwait (0-1), Libya (0-2), Malaysia (5-1), Maldives (5-3), Myanmar (0-3), Oman } \\ \text { (0-1), Qatar (0-2), Seychelles (3-3), Sierra Leone (0-3), Singapore (0-1), Sudan (0-4), Swaziland (0-3), Tanzania (0-4), Uganda (0-4), } \\ \text { United Arab Emirates (0-1), Zambia (5-3), Zimbabwe (0-1) }\end{array} \\ \hline\end{array}$


experienced much shorter interludes of democratic rule. The scale in terms of adopted constitutions is in like manner wide: some countries have so far adopted one constitution only; others have introduced three (Fiji, Gambia, Sri Lanka) or even four (Ghana) or five (Nigeria) constitutions. The average endurance score in this group is 2.14 , a mark that is clearly higher than in the democracy group and close to the respective mark in the non-democracy group. The finding, then, sustains again the notion of a link between democracy and endurance. Interestingly, an internal democracy-related as well as endurance-related dividing line may be detected in the materials in this group, as the six countries that are close or fairly close to a democracy status are precisely those that have good endurance performances, whereas, on the other hand, the four countries that perform poorly in terms of democracy all represent less satisfying endurance records as well. Again, this is much in line with the assumption that democracy fosters endurance.

The overall conclusion from this exercise is likewise in line with the above assumption. Almost all democracies have adopted no more than one constitution; close to two thirds of the other states have adopted two or more constitutions, more than one third of these other states have adopted three or more constitutions. A pattern is clearly there: democracy links to endurance, whereas non-democracy and semi-democracy do not.

\section{On Amendment}

To repeat, the statement that democracy sustains endurance appears well substantiated. Still, the statement may be an oversimplification that stems from the conceptualization of endurance to mean total constitutional change, i.e. the replacement of one constitution by a new constitution. The endurance concept, however, should preferably enclose also amendments, i.e. formal and partial changes to the text of the constitution. Such changes imply that portions of the original text of the constitution are deleted or that new articles are inserted in the text; amendments may of course also be appended as special articles to the main text of the constitution. Now, democracies may be inclined to resort more than other systems to such less drastic mechanisms for reform and thereby for non-endurance - when and if that happens, it may be the case that the difference between democratic entities and others in regards to endurance is to some extent at least smoothened out.

As evident from selected observations, the empirical basis for a belief that democracies are particularly prone to engage in amendment politics appears to be somewhat shaky. Whereas amendments are less frequent in some democratic countries, like Australia, they form a much more recurrent ingredient of constitutional life in other places, like India, where more than 110 amendments have over the years been made to the 1949 Constitution, and United States, where 27 amendments have been ratified since the signing of the 1789 constitution. About several other places it is perhaps difficult to say whether or not the amendment rates are considerable or moderate. In South Africa there have been 16 constitutional amendments passed since 1996 (Dixon, 2011: p. 98); in Papua New Guinea, unstable but overall democratic, the 1975 constitution has been amended more than twenty times (Grote, 2009a: p. 6). In Mauritius, "one of the few African countries in which a multi-party system has been maintained since independence, and where competitive elections have been held almost regularly" (Krennerich, 1999a: p. 603), the 1968 constitution is amended ten times (Angelo \& Gordon, 1998, 2001). The 1966 independence constitution of another African state, Botswana, once characterized as "one of the economic and political success stories in a continent that is usually excoriated for an unsatisfactory postcolonial democratic record" (Dale, 1999: p. 128), has been amended more than twenty times, but none of the amendments has been significant enough to change the basic framework and structure of the constitution (Fombad, 2011: p. 4).

In like manner, the parallel expectation that non-democracies are less inclined to resort to the method of amendment appears to have a less than overwhelming empirical support. Some cases clearly contradict the expectation. Take Singapore, for example - the constitution of that country has been amended and revised multiple times; in the years 2001-2008 alone the constitution was amended six times (Grote, 2009b: pp. 3-6). Malaysia is a similar case. According to one count, the constitution was amended 42 times over the years since independence as of 2005, the number of individual amendments exceeding 600 (Faruqi, 2008). The 1993 constitution of Seychelles was amended already in 1994 and again twice in 1995 and once in 1996 (Ruchti, 2004: pp. v-xii). On the other hand, the 1993 constitution of Russia had only in 2008 its first significant amendment (Grote, 2010: pp. 3-11), the 1994 constitution of Belarus has been amended twice since the original adoption; however, the 1996 amendment was in fact so extensive that it is being referred to as a new constitution (Flanz, 1997: p. vii), the constitution of Equatorial Guinea, approved in 1991, has since been amended twice, etc., etc.

However, as mentioned, these are only scattered examples. More encompassing mappings and reviews of the 
use and impact of the amendment institution are so far lacking, and this shortcoming no doubt reflects a wellrecognized need for the general study of comparative constitutional law to exploit a broader empirical base. "It is probably the case that $90 \%$ of comparative work in the English language covers the same ten countries, for which materials are easily accessible in English", it is said in the introductory chapter of an important collection of writings on constitutional law (Dixon \& Ginsberg, 2011: p. 13); the same authors further emphasize that "the field needs many more studies of the operation of constitutions and constitutional law in less well-studied contexts, including non-democracies” (Dixon \& Ginsberg, 2011: p. 13). These are apposite observations, also in the amendment framework, which would probably benefit much from comparisons of the use of the institution in democracies and non-democracies alike.

Still, the lack of robust empirical evidence notwithstanding, theoretical arguments may be found to support the belief that democracies resort to amendment to a higher extent than non-democracies. One important argument follows from the assumption that democracies are as a rule more stable polities, and for that reason also to some extent tardy and gradual, meditative in nature. A certain extent of inertia is probably a characteristic of the constitutional policies in democracies and serves to counter-check abrupt and ill-considered constitutional oscillation and fluctuation. In other words, changes are in democracies well-prepared, thought through and moderate in terms of content as well as frequency-rather than settle accounts once and for all with the past and rejecting constitutional totalities, democracies may be expected to aim at piecemeal engineering, patching up and repairing, adapting constitutional parts and details in accordance with what necessity demands. Another and related important argument may be derived from the assumption that the function of constitutions is somewhat different in democratic than in non-democratic contexts (Derbyshire \& Derbyshire, 1999: p. 16)—above all, the very tension between majority will and minority protection that is embedded in the democratic way of structuring government is not at issue to the same extent in non-democratic entities, which may be supposed to maintain a weaker commitment to popular rule. From this follows that considerations that apply to social inclusion and the systematic consultation of participatory institutions are supposedly more frequent features in democratic than in non-democratic constitutional engineering; from this follows, in turn, a firmer and more common commitment to the constitution and a hesitant unwillingness to endorse changes that abolish in full what has earlier been accomplished. Anyhow, reasonable as such assumptions may be, at the present stage of research the question of their validity must remain open.

Generally speaking, the amendment institution relates functionally to endurance in two parallel but still different ways. First, amendments undermine endurance: they imply partial changes in prevailing orders and frames of reference and thereby shorten the life span of the relevant stipulations. To amend, therefore, is to tear down and replace. Second, however, amendments are also endurance-sustaining in so far as they by the introduction of partial reforms make possible the survival of the whole, parts of which have been exchanged. This second function much comes to the front in the framework of very old constitutions. As is well known, several countries have or have had such constitutions-examples besides United States, Norway and Luxembourg are Belgium, Mexico, Sweden (1809-1974), Switzerland (1874-2000) and Tonga. This reliance on old-world documents and principles creates all sorts of problems for the daily conduct of governance and political life, and a simple solution to these problems is of course the resort to total constitutional change, as in Sweden and Switzerland. "It was the faulty correspondence between the stipulations of the Form of Government Act and the working polity that released the constitutional reform", it is said (my translation) in a volume that explains the transition in Sweden from the 1809 Form of Government Act to the 1974 constitution (Holmberg \& Stjernquist, 1992: p. 31). Such constitutional turnovers, however, are for reasons of reverence and for other reasons not always a passable method-Norway is one example (e.g. Petersson, 1998: pp. 22-23; Helander, 1988: pp. 108-111). When this is the case, besides the various mechanisms offered by the method of judicial review, amendment stands out as a possible remedy. Again, Norway serves as one example: since the introduction in 1814 of the now archaic constitution, more than 200 amendments have been adopted (Rasch \& Congleton, 2006: p. 320). Comparative and empirical studies of the use of amendments in the management of aged constitutions would no doubt much enrich a field of study which is hitherto heavily dominated by considerations on what has been and is going on in an American context.

\section{On Regions}

Endurance differences are not only between countries but also between regions. To some extent differences between regions are even self-reinforcing. This is when constitutional changes come about as consequences of 
diffusion: constitutions are replaced by new ones because similar replacements have occurred in neighboring countries. Sometimes regional patterns emerge in consequence of particular events and crises that take place in a certain geographical space and overthrow the constitutional climate of that space. An evident example is the large number of new constitutions that were introduced in Eastern Europe following the collapse of communism and the breakdown of former Soviet and communist regimes (Vereshchetin, 1996). Including Croatia (1990), Czech Republic (1992), Estonia (1992), Georgia (1995), Kazakhstan (1995), Macedonia (1991), Moldova (1994), Tajikistan (1994), Uzbekistan (1991), and others, new countries, regimes and constitutional arrangements emerged and became members and parts of the international community.

Africa is an interesting region, as it displays several diffusion cases, but also because the developments illustrate the brittleness of the not uncommon belief that endurance is in itself and by necessity a valuable thing. Introducing as editors a comprehensive data handbook on "Elections in Africa", Nohlen, Krennerich and Thibaut (1999) note that most of the African states that attained independence in the 1950s and the 1960s were equipped by the former colonial powers with liberal-democratic constitutions (p. 3). As also noted by the same editors, these imported constitutional regulations hardly ever worked and were soon either withdrawn, fundamentally modified or simply ignored (p. 3). The regulations were in the minds of opponents and adversaries incongruent with the widely spread belief that traditional African societies rested on a politics of consensus and that a system of one-party government therefore was an essential part of the African tradition (Uwizeyimana, 2012: p. 140). Accordingly, the regulations were in most cases replaced with arrangements that corresponded to "the African understanding that a Government or ruler is the one that decides when to come down, and the natural time is when a ruler dies. In other words, African rulers, Prime Ministers and Presidents, soon see themselves as taking the place of Kings, and that is the way the electorate of the ruling Party sees the situation too" (Machobane, 2010: p. 9). In compliance, a great majority of the African states, Algeria, Burundi, Cameroon, Djibouti, Equatorial Guinea, Guinea, Malawi, Rwanda, and many others soon introduced a single-party system which implied the constitutional abolition of multi-partyism and the banning of opposition parties. Western-styled constitutions did not endure; in their place came constructs of un-democracy, oppression, and authoritarianism.

The pattern again changed, however, in the late 1980s and during the following decade, which was a time of vehement constitutional reconstruction and reform. Indeed, of more than 80 constitutions introduced in the world in the 1990s, no less than 38 were adopted by African states (Derbyshire \& Derbyshire, 1999: p. 12). The changes implied a democratization phase as multi-party systems were now introduced and re-introduced in several countries, as multi-party elections took place with notable regularity, as a sense was growing among elites and masses alike that competitive elections are the only legitimate way to choose national leaders, and, importantly, as many founding elections in fact led to a change of regime (Nohlen, Krennerich, \& Thibaut, 1999: pp. 9-15). In fact, still in the early 1980s no national government in an independent African state had ever been transferred to an opposition by electoral means (Sklar, 1983: pp. 12-13). It would seem, by the way, that the democracy-enhancement qualities of small state size (e.g. Srebrnik, 2004) may be found also on the African continent: of altogether 11 African democracies in 2006, more than half were countries with populations of less than two million, and whereas half of the African microstates with populations of one million or less were democracies in 2006, the same was true of only one fifth of the larger states (Anckar, 2008: pp. 80-82). Anyhow, in Africa a diffusion-inspired period of low endurance, independence constitutions soon being overthrown and redrafted all over the continent, has had in its wake another diffusion-inspired period of low endurance, as constitutions in want of democracy now are replaced by means of a democratization wave, the final outcomes of which are yet to be seen but which surely carries promises for the future. Endurance is often assumed to have inherent and good consequences, for instance in terms of stability. While much can certainly be said to support such a belief, there is still no automatic link between endurance and good consequences. It all depends, not least on the quality and nature of what endures and becomes stable. If the question of the value of endurance is opened to include also an evaluation of the matters and principles that endure, the repeated African endurance gaps may in the long run have proved beneficial to political development.

\section{On Rigidity}

Several studies in the field of endurance are about rigidity, i.e. the difficulty of the constitutional amendment process. The guiding expectation in research is that systems which have adopted a high degree of rigidity are less inclined than low-rigidity systems to introduce constitutional change: other things being equal, one would 
certainly expect low-rigidity countries to engage in constitutional change to a much larger extent than high-rigidity countries. Empirically, however, the relation between rigidity and endurance is less straightforward. The study by Elkins, Ginsburg and Melton (2009) suggests that the relation, although positive, is anything but linear; other findings, equally undecided, tend to support this statement. While some authors point to a negative correlation between the difficulty of amendment and the rate of amendment (e.g. Lutz, 1994), others fail to note such a correlation (e.g. Ferejohn, 1997). Indeed, reviewing the capacity of several rigidity conceptions to explain amendment variation, Lorenz (2005) makes the observation that the conceptions produce "strikingly different results” (p. 339). In consequence, she poses the question if the pro-intuitive effect of institutional rigidity has been overestimated, and she states that it is a challenge to the further debate on constitutional politics to solve this puzzle (Lorenz, 2005: p. 355).

There are perhaps several reasons why the findings remain inconsistent and even contradictory. For one thing, authors tend to define and operationalize the rigidity notion in different ways: when and if the key concept remains vague and methods of operationalizations abound, little wonder if the findings diverge. So far, no generally agreed taxonomy with ensuing categorizations and classifications exists, and the worked-out efforts in that direction are few in number (see, however, Anckar, 2013). Second, research on rigidity tends to be hampered by too many efforts being in the case-study or small-N departments and too few efforts aiming at more encompassing research. Commenting on the state of research on constitutional amendment rules, Rosalind Dixon finds one potential reason for inconsistency in the small number of independent observations that is characteristic of many efforts in this area. The number, she argues, is "sufficiently small that there is not enough statistical power to pick up the distinct effect of various hurdles to amendment” (Dixon, 2011: p. 105). No doubt, the characterization is valid in respect to rigidity research as well. However, to insert a note in passing, this is a criticism that does not target comparative constitutional law alone, but is equally in place when it comes to the field of comparative politics, still imbued by research on limited samples of countries (Peters, 1998: pp. 137-155).

Furthermore, as noted by several authors, the rigidity factor may play different and contradictory roles in the frameworks of total constitutional change on the one hand and constitutional amendment on the other. It is easy to understand that a flexible, i.e. non-rigid system that allows for frequent constitutional amendments may increase the likelihood of whole-scale constitutional replacement (e.g. Dixon, 2011: p. 102); this happens when the inflow of amendments becomes so abundant that it turns uncontrollable and evokes non-endurance, i.e. large-scaled constitutional change. In such situations rigidity emerges as a good thing, as a gate-keeper that protects and safeguards endurance. On the other hand, however, an overly rigid system may be like manner undermine endurance. This happens when partial constitutional change is made so difficult to achieve that a wholescale effort appears the right solution. Rigidity may, in other words, exist in portions that are too small or too large to prevent the collapse of endurance; such portions are likely in the short run (not enough rigidity) and the long run (too much rigidity) to undermine the stability of the constitutional framework. At present, not nearly enough is known about what is too little or too much in this respect and what internal and external circumstances may contribute to evaluations of rigidity quantities. Clearly, there is a need for research that seeks out proper intervals and calculates the amount and scope of proper rigidity inputs. Again, however, such research efforts must build on worked-out rigidity taxonomies and accompanying classifications, and such constructs are at the present stage of research in short supply.

One specific rigidity case is clearly under-researched; this is the case of absolute rigidity, this meaning the use of entrenched clauses to restrict amendments to which they may be subject. In other words, absolute rigidity means that certain changes, which are usually thematically defined, are simply forbidden. Examples abound. For instance, the constitution of the Czech Republic states (article 9) that "any change of fundamental attributes of the democratic law-observing state is inadmissible"; the 1990 constitution of Benin states (§ 156) that "The republican form of government and the secularity of the state may not be made the object of a revision"; the 1987 constitution of Haiti states (§ 284-4) that "No amendment of the Constitution may affect the democratic and republican nature of the State"; and the 1979 constitution of Iran declares (article 177) several items to be "unalterable", including "the Islamic character of the political system", "the religious footing", "the objectives of the Islamic Republic of Iran", and "the holy principle".

One may of course use varying notions to understand why some countries have introduced instances of absolute rigidity whereas others have not, and why specific and different issues are targeted in different systems. One possible point of departure is that an absolute rigidity implies a curtailment on the rights of the parliament and a definite interference with the sovereignty of parliament and other institutions of decision-making. In a manner of 
speaking this arrangement, then, involves a de-politization of specific issues and principles. Given this consequence, a reasonable expectation is that variation in the use of absolute rigidity may follow from differences in the extent to which the relevant political systems maintain strong or weak parliaments that may be supposed to offer or withhold resistance to encroachments on their areas of competence. About such differences it has been said that "most legislatures can be identified as either policy-influencing legislatures or legislatures with only marginal policy effect” (Baldwin, 2013: p. 4); from this distinction would follow that states with legislatures in the first category are less inclined than states in the second category to pursue an absolute rigidity. Also, the democracy status of countries possibly emerges as a worthwhile explanatory factor, although the direction of the impact of this factor is not at all evident. On the one hand, the expectation would be that democracies tend to look with restraint on efforts to reduce the right of political institutions to initiate and make decisions-in a democratic view, electors and their representatives should always have the right to look over and revise the content of politics, including constitutional prescriptions. Democracies, then, would hesitate to engage in establishing modes of absolute rigidity. On the other hand, however, it is an equally reasonable expectation that democracies take a special interest in the preservation of democratic methods and ideals and therefore find it only natural to introduce by means of absolute rigidity a constitutional ban on attempts to abandon the democratic system of government.

\section{References}

Anckar, D. (2008). Microstate Democracy Revisited: Developments in Time and Space. The Open Political Science Journal, 1, 75-83. http://dx.doi.org/10.2174/1874949600801010075

Anckar, D. (2011). Democracy as a Westminster Heritage. Taiwan Journal of Democracy, 7, 47-71.

Anckar, D. (2013). Hur kan konstitutionell rigiditet mätas? Politiikka, 55, 168-179.

Angelo, A. H., \& Gordon, R. (1998, 2001). Mauritius. Introductory and Comparative Notes. In G. H. Flanz (Ed.), Constitutions of the Countries of the World, Binder XII, Release 98-6, 2001-6. New York: Oceana Publications.

Baldwin, N. D. (2013). Introduction I. Legislatures. In N. D. Baldwin (Ed.), Legislatures of Small States: A Comparative Study (pp. 1-11). London and New York: Routledge.

Dale, R. (1999). Republic of Botswana. In D. A. Kaple (Ed.), World Encyclopedia of Political Systems and Parties, Vol. 1 (3rd ed., pp. 128-131). New York: Facts on File.

Derbyshire, J. D., \& Derbyshire, I. D. (1999). Political Systems of the World, Vol. 1. Oxford: Helicon Publishing.

Dixon, R. (2011). Constitutional Amendment Rules: A Comparative Perspective. In T. Ginsberg, \& R. Dixon (Eds.), Comparative Constitutional Law (pp. 96-111). Northampton, MA: Edward Elgar. http://dx.doi.org/10.4337/9780857931214.00012

Dixon, R., \& Ginsberg, T. (2011). Introduction. In T. Ginsberg \& R. Dixon (Eds.), Comparative Constitutional Law (pp. 1-18). Northampton, MA: Edward Elgar. http://dx.doi.org/10.4337/9780857931214.00006

Elkins, Z., Ginsberg, T., \& Melton, J. (2009). The Endurance of National Constitutions. New York: Cambridge University Press. http://dx.doi.org/10.1017/CBO9780511817595

Faruqi, S. S. (2008). Document of Destiny-The Constitution of the Federation of Malaysia. Shah Alam: Star Publications.

Ferejohn, J. (1997). The Politics of Imperfection: The Amendment of Constitutions. Law and Social Inquiry, 22, 501-530. http://dx.doi.org/10.1111/j.1747-4469.1997.tb00881.x

Flanz, G. H. (1997). Belarus. Introductory \& Comparative Notes. In G. H. Flanz (Ed.), Constitutions of the Countries of the World, Binder II, Release 97-3 (pp. vii-xii). New York: Oceana Publications.

Flanz, G. H. (Ed., various years). Constitutions of the Countries of the World. New York: Oceana Publications.

Fombad, C. M. (2011).The Republic of Botswana. Introductory Note. In G. H. Flanz (Ed.), Constitutions of the Countries of the World, Binder III, Release 2011-5 (pp. 1-38). New York: Oceana Publications.

Ginsberg, T. (2011). Constitutional Endurance. In T. Ginsberg, \& R. Dixon (Eds.), Comparative Constitutional Law (pp. 112-125). Northampton, MA: Edward Elgar. http://dx.doi.org/10.4337/9780857931214.00013

Grote, R. (2009a). The Independent State of Papua New Guinea. Introductory Note. In G. H. Flanz (Ed.), Constitutions of the Countries of the World, Binder XIV, Release 2009-4 (pp. 1-8). New York: Oceana Publications.

Grote, R. (2009b). The Republic of Singapore. Introductory Note. In G. H. Flanz (Ed.), Constitutions of the Countries of the World, Binder XVI, Release 2009-2. New York: Oceana Publications.

Grote, R. (2010). The Russian Federation. Introductory Note. In G. H. Flanz (Ed.), Constitutions of the Countries of the World, Binder XV, Release 2010-1 (pp. 3-11). New York: Oceana Publications. 
Helander, V. (1988). Pohjoismaiden poliittiset järjestelmät. Turku: Turun yliopisto, valtio-oppi, valtio-opillisia tutkimuksia, n:o 44.

Holmberg, E., \& Stjernquist, N. (1992). Vår författning. Stockholm: Norstedts Juridik.

Krennerich, M. (1999a). Mauritius. In D. Nohlen, M. Krennerich, \& B. Thibaut (Eds.), Elections in Africa: A Data Handbook (pp. 603-622). Oxford: Oxford University Press. http://dx.doi.org/10.1093/0198296452.003.0034

Krennerich, M. (1999b). Zambia. In D. Nohlen, M. Krennerich, \& B. Thibaut (Eds.), Elections in Africa: A Data Handbook (pp. 939-962). Oxford: Oxford University Press. http://dx.doi.org/10.1093/0198296452.003.0053

Lorenz, A. (2005). How to Measure Constitutional Rigidity. Journal of Theoretical Politics, 17, 339-361. http://dx.doi.org/10.1177/0951629805052883

Lutz, D. S. (1994). Toward a Theory of Constitutional Amendment. American Political Science Review, 88, 355-370. http://dx.doi.org/10.2307/2944709

Machobane, L. B. B. J. (2010). A Microscopic View into Lesotho’s Forty Year Period of Independence: 1966-2006.

Nohlen, D., Krennerich, M., \& Thibaut, B. (1999). Elections and Electoral Systems in Africa. In D. Nohlen, M. Krennerich, \& B. Thibaut (Eds.), Elections in Africa. A Data Handbook (pp. 1-40). Oxford: Oxford University Press. http://dx.doi.org/10.1093/0198296452.001.0001

Peters, B. G. (1998). Comparative Politics. Theory and Methods. London: Macmillan Press.

Petersson, O. (1998). Nordisk politik, fjärde upplagan. Stockholm: Norstedts Juridik.

Rasch, B. E., \& Congleton, R. D. (2006). Amendment Procedures and Constitutional Stability. In R. D. Congleton, \& B. Swedenborg (Eds.), Democratic Constitutional Design and Public Policy (pp. 319-342). Cambridge, MA: MIT University Press.

Ruchti, J. J. (2004). Republic of Seychelles. Introductory and Comparative Notes. In G. H. Flanz (Ed.), Constitutions of the Countries of the World, Binder XVI, Release 2004-1 (pp. v-xii). New York: Oceana Publications.

Sklar, R. L. (1983). Democracy in Africa. African Studies Review, 26, 11-24. http://dx.doi.org/10.2307/524160

Somoza, A. (2001). Tuvalu. In D. Nohlen, F. Grotz, \& C. Hartmann (Eds.), Elections in Asia and the Pacific. A Data Handbook, Vol. II (pp. 823-832). Oxford: Oxford University Press. http://dx.doi.org/10.1093/0199249598.003.0030

Srebrnik, H. (2004). Small Island Nations and Democratic Values. World Development, 32, 329-341. http://dx.doi.org/10.1016/j.worlddev.2003.08.005

Thibaut, B. (1999). Seychelles. In D. Nohlen, M. Krennerich, \& B. Thibaut (Eds.), Elections in Africa: A Data Handbook (pp. 775-788). Oxford: Oxford University Press. http://dx.doi.org/10.1093/0198296452.003.0043

Uwizeyimana, D. E. (2012). Democracy and Pretend Democracies in Africa: Myths of African Democracies. Law, Democracy and Development, 16, 139-161.

Vereshchetin, V. (1996). New Constitutions and the Old Problem of the Relationship between International Law and National Law. European Journal of International Law, 7, 29-41. http://dx.doi.org/10.1093/oxfordjournals.ejil.a015502 